\title{
IMPLEMENTASI PP NO. 27 TAHUN 1998 TENTANG PENGGABUNGAN PELEBURAN DAN PENGAMBILALIHAN PERSEROAN TERBATAS DENGAN BERLAKUNYA UU NO. 40 TAHUN 2007
}

\author{
Sukirman \\ Fakultas Hukum Universitas Jenderal Soedirman Purwokerto, Jawa Tengah
}

\begin{abstract}
Incorporated Company is one of the most preferred form of the Company by Entrepreneur and holds an important role in mobilizing the National Economic Development. To develop incorporated company to become a healthy business, can be reach by the expansion that can be done through Merger, Consolidation and Acquisition. From those three forms, takeovers is considered more practical and profitable for the company to develop their business, because there are no company that merged or disbanded. In the implementation, the enactment of Law Number 40 Year 2007 concerning Incorporated Company are not followed by the promulgation of Regulation of the implementation of the Act. This causes the interested parties still refer to the former regulations. The problems that arise is how the implementation of Government Regulation No.27 year 1998 about Merger, Consolidation, and Acquisition of Limited Liability Company with the enactment of Law No.40 Year 2007. Based on the analysis, it known that the enactment of Law No.40 Year 2007 concerning Incorporated Company, Government Regulation No.27 Year 1998 concerning Merger, consolidation, and Acquisition still in force. In addition, Merger, consolidation, and acquisition is still based on Government Regulation No.27 Year 1998 and Article 134 of Company Law.
\end{abstract}

Keywords: Merger, Consolidation, and Acquisition.

Abstrak

Perseroan Terbatas adalah bentuk perusahaan yang diminati oleh pengusaha dan memegang peranan penting dalam menggerakkan dan menggairahkan kegiatan pembangunan perekonomian nasional. Untuk mengembangkan Perseroan Terbatas agar menjadi sehat, dapat dicapai melalui ekspansi perusahaan dalam bentuk merger, konsolidasi dan akuisisi perusahaan. Dari tiga bentuk pengambilalihan tersebut dianggap lebih praktis dan menguntungkan bagi perusahaan yang akan mengembangkan bisnis mereka, karena tidak ada perusahaan yang digabungkan atau dihilangkan.Dalam pelaksanaannya, Undang-Undang Nomor 40 Tahun 2007 tentang Perusahaan Terbatas tidak diikuti dengan Peraturan pelaksanaanya. Hal ini menyebabkan pihak yang berkepentingan masih harus mengacu pada peraturan pelaksanaan yang lama. Masalah yang timbul adalah bagaimana pelaksanaan Peraturan Pemerintah No.27 tahun 1998 tentang Merger, Konsolidasi, dan Akuisisi Perseroan Terbatas dengan Undang-undang No.40 Tahun 2007. Bedasarkan analisis dapat diketahui bahwa berlakunya Undang-Undang No.40 Tahun 2007 tentang Perusahaan Terbatas, Peraturan Pemerintah No.27 Tahun 1998 tentang Merger, konsolidasi, dan Akuisisi masih berlaku. Selain itu, Merger, konsolidasi, dan akuisisi dalam penerapannya masih didasarkan pada Peraturan Pemerintah No.27 Tahun 1998 dan Pasal 134 Undang Undang Perseroan Terbatas.

Kata kunci: Merger, Konsolidasi, dan Akuisisi.

\section{Pendahuluan}

Sejak 1967, keberadaan Perseroan terbatas memegang peranan penting dan strategis dalam menggerakkan dan menggairahkan kegiatan pembangunan perekonomian nasional di Indonesia. Hal ini ditandai dengan banyaknya orang yang berlomba-lomba untuk mendirikan perusahaan yang berbentuk Perseroan Terbatas (PT). Salah satu faktor yang memicu perkembangan dan peertumbuhan PT adalah karena dikeluarkannya Undang-Undang Nomor 1 Tahun 1967 tentang Penanaman Modal Asing 
(UUPMA). UUPMA ini mengharuskan kegiatan penanaman modal, terutama kegiatan penanaman modal asing dilakukan dalam bentuk badan usaha yang berbentuk PT. ${ }^{1}$

Mengenai pengertian "Perseroan Terbatas" dalam peraturan perundang-undangan di Indonesia, dapat ditemukan pada undangundang nomor 40 tahun 2007 tentang Perseroan Terbatas (selanjutnya disebut UUPT) Pasal 1 angka (1) Undang-undang tersebut yang menentukan:

Perseroan Terbatas, yang selanjutnya disebut Perseroan, adalah badan hukum yang merupakan persekutuan modal, didirikan berdasarkan perjanjian, melakukan kegiatan usaha dengan modal dasar yang seluruhnya terbagi dalam saham dan memenuhi persyaratan yang ditetapkan dalam Undang-Undang ini serta peraturan pelaksanaannya.

Dari pengertian yang diberikan tersebut di atas ada lima hal pokok yang dapat dikemukakan mengenai PT meliputi Pertama, merupakan suatu badan hukum; Kedua, didirikan berdasarkan perjanjian; Ketiga, menjalankan usaha tertentu; Keempat, memiliki modal yang terbagi dalam saham-saham; Kelima, memenuhi persyaratan undang-undang. ${ }^{2}$

Sebagai badan hukum, PT merupakan subjek hukum yang mempunyai hak-hak dan kewajiban-kewajiban perdata, dapat digugat dan menggugat di depan hakim. Pasal 7 ayat (5) UUPT menentukan bahwa Perseroan memperoleh status badan hukum pada tanggal diterbitkannya Keputusan Menteri mengenai pengesahan badan hukum perseran. Dengan demikian status badan hukum PT diperoleh sejak akta pendirian badan hukum PT tersebut disahkan menteri (dalam hal ini Menteri Hukum dan HAM).

Kata "Perseroan" menunjuk kepada modalnya yang terdiri atas sero (saham). Sedangkan kata "terbatas" menunjuk kepada tanggung jawab pemegang saham yang tidak melebihi

Yahya Harahap,2009, Hukum Perseroan Terbatas, Jakarta:Sinar Grafika, hlm.11

2 Gunawan Wijaya dan Ahmad Yani, 2000, Seri Hukum Bisnis; Perseroan Terbatas, Jakarta :Rajawali Press, hlm. 1 nilai nominal saham yang diambil bagian dan dimilikinya. Karena modalnya terdiri dari saham-saham yang dapat diperjualbelikan, perubahan kepemikinan perusahaan dapat dilakukan tanpa perlu membubarkan perusahaan. ${ }^{3}$

PT merupakan badan usaha dan besarnya modal Perseroan tercantum dalam anggaran dasar. Kekayaan perusahaan terpisah dari kekayaan pribadi pemilik perusahaan sehingga memiliki harta kekayaan sendiri. Setiap orang dapat memiliki lebih dari satu saham yang menjadi bukti pemilikan perusahaan. Perseroan sebagai badan hukum memiliki modal dasar yang disebut juga Auwhorized capital, yakni jumlah modal yang disebutkan atau dinyatakan dalam akta pendirian atau Anggaran Dasar Perseroan. ${ }^{4}$

Selain ditentukan dalam peraturan perundang-undangannya, pemilihan bentuk badan usaha PT juga banyak dilakukan karena banyaknya keuntungan yang diperoleh dengan dipilihnya bentuk badan usaha PT ini. Sri rejeki Hartono mengemukakan alasan sebagai berikut.

PT pada umumnya mempunyai kemampuan untuk mengembangkan diri, mampu mengadakan kapitalisasi modal dan sebagai wahana yang potensiil untuk memperoleh keuntungan baik bagi instansinya sendiri maupun bagi para pendukungnya (pemegang saham). Oleh karena itu, bentuk badan usaha ini sangat diminati oleh masyarakat. ${ }^{5}$

Pendapat ini mendasarkan pada kenyataan bahwa PT mempunyai kemampuan untuk mengembangkan diri dan dapat memberikan keuntungan baik kepada organisasinya maupun kepada para pemegang sahamnya. Lebih lanjut Sri Rejeki Hartono mengatakan: Masih terdapat beberapa alasan praktis, antara lain: Pertama, setiap jenis usaha mempunyai jankakuan relatif luas, pada izin operasionalnya selalu menatkan bahwa perusahaan yang bersangkutan harus berbentuk badan hukum (pilihan utama pasti Perseroan terbatas);

3 Muh.Afni Nazar, 2000. Kamus Lengkap Ekonomi, Jakarta:Citra Harta prima, hlm 98

$4 \quad$ Sri Rejeki Hartono, 1995. Beberapa Aspek Permodalan Pada Perseroan Terbatas, Yogyakarta.hlm. 2

Ibid, hlm. 6 
Kedua, setiap jenis usaha yang bergerak di bidang keuangan diisyaratkan dal bentuk badan hukum, pilihan utama adalah juga Perseroan terbatas; Ketiga, perusahaan yang berpeluang memanfaatkan bursa modal hanyalah Perseroan terbatas, maka sangat wajar apabila peningkatan jumlah PT di Indonesia semakin besar. ${ }^{6}$

Untuk memberikan kesempatan kepada PT untuk tumbuh dan berkembang diperlukan iklim usaha yang sehat dan efesien. Untuk menciptakan iklim usaha yang sehat dan efesien salah satunya dapat dilakukan dengan perluasan atau ekspansi perusahaan. Perluasan atau ekspansi perusahaan ini dapat dilakukan melalui penggabungan, peleburan, atau pengambilalihan perusahaan akan tercipta persaingan yang sehat dan kompetitif diantara PTPT yang ada. Hal ini karena hanya PT-PT yang sehat dan kompetitif saja yang akan bertahan, karena mampu memenuhi kebutuhan dan dapat diterima pasar. Namun demikian upaya untuk menciptakan iklim usaha yang sehat dan efisien ini harus tetapmengacu pada asas pembangunan ekonomi nasional sebagaimana diamanatkan oleh Pasal 33 UUD 1945 dimana asa pembangunan ekonomi nasional yang dianut oleh negara kita adalah asas kekeluargaan.

Berdasarkan pemikiran tersebut maka upaya penciptaan iklim dunia usaha yang sehat dan efisien tidak boleh mengarah pada penguasaan dan pemusatan kekuatan sumber daya ekonomi pada suatu kelompok atau golongan tertentu saja. Oleh karena itu tindakan pengembangan dan perluasan usaha melalui penggabungan, peleburan, atau pengambilalihan PT harus memperhatikan kepentingan Perseroan, pemegang saham, karyawan Perseroan dan masyarakat, termasuk pihak ketiga yang berkepentingan, agar tindakan pengembangan dan perluasan usaha melalui penggabungan, peleburan, atau pengambilalihan PT yang mendorong ke arah terjadinya monopoli, monopsoni atau persaingan usaha tidak sehat dapat dicegah dan dihindari sejak awal.

Salah satu bentuk perluasan atau ekspansi prusahaan yang banyak dilakukan adalah dengan melakukan akuisisi atau pengambilalihan perusahaan. Akuisisi menjadi cara pengembangan eksternal yang banyak dilakukan perusahaan atau grup perusahaan, karena Perseroan terbatas (PT) merupakan bentuk organisasi perusahaan (BOP) yang banyak dipergunakan dan akomodaif terhadap penanaman modal langsung (PML) dan penanaman modal tidak langsung (PMTL) baik dari dalam negeri maupun luar negeri. ${ }^{7}$

Berbeda dengan Merger dan konsolidasi, di dalam akuisisi tidak ada perusahaan yang meleburkan diri atau membubarkan diri. Dengan akuisisi tidak ada perusahaan yang lenyap dan tidak ada pula perusahaan yang baru yang terbentuk. Hal ini dianggap lebih praktis bagi perusahaan-perusahaan yang akan memperluas dan mengembangkan usahanya karena tidak perlu diadakan suatu pendaftaran perusahaan baru ataupun suatu perubahan Anggaran Dasar prusahaan.

Berdasarkan uraian latar belakang masalah tersebut di atas, maka dapat dirumuskan permasalahan: Bagaimana Implementasi Peraturan Pemerintah Nomor 27 tahun 1998 tentang Penggabungan, Peleburan, dan Pengambilalihan Perseroan Terbatas dengan berlakunya Undang-Undang Nomor 40 Tahun 2007 tentang Perseroan Terbatas.

\section{Pembahasan}

\section{Penggabungan (Merger)}

Mengenai pengertian dari penggabungan/Merger, tercantum dalam Pasal 1 angka (9) UUPT yang menentukan:

Penggabungan adalah perbuatan hukum yang dilakukan oleh satu Perseroan atau lebih untuk menggabungkan diri dengan Perseroan lain yang telah ada yang mengakibatkan aktiva dan pasiva dari Perseroan yang menggabungkan diri beralih karena hukum kepada Perseroan yang menerima penggabungan dan selanjutnya status badan hukum Perseroan yang menggabungkan diri berakhir karena hukum. 
Merger menurut definisi yang diberikan dalam Encyclopedia of Banking and Finance adalah:

a combination of two or more corporations, where the dominant unit absorbs the passive unit, the farmer continuing operations, usually under the same name.

Menurut jenisnya, Merger meliputi. Pertama, Merger konglomerat (conglomerate Merger), dimana perusahaan-perusahaan yang bergabung bukanlah competitor, pelanggan atau pemasok yang satu terhadap yang lainnya, seperti halnya Merger horizontal dan Merger vertiikal. Tipe Merger konglomerat ini dibedakan lagi dalam jenis Tipe perluasan geografis (Geographic Extension), dipakai guna memperluas pangsa pasar; Tipe perluasan produk (Product Extension), dilakukan antara sesama produsen dari barang-barang yang mirip atau hampir sejenis, tetapi bukan kompetitor; Tipe konglomerat murni (Pure Conglomerate Merger), merupakan Merger dari dua perusahaan, dimana perusahaan-perusahan yang bergabung tersebut tidak memiliki pangsa pasar yang hampir sejenis, ataupun secara fungsional tidak memiliki pangsa pasar yang hampir sejenis, ataupun secara fungsional tidak memiliki hubungan ekonomis, seperti kedua tipe diatas. Kedua, Merger dalam satu grup, yang dibedakan dalam: tipe down stream Merger, dimana induk perusahaan Merger masuk ke dalam anak perusahaan; dan kebalikannya tipe up stream marger, dimana anak perusahaan masuk ke dalam induk perusahaannya. Ketiga, Merger horizontal, yang terjadi antar kompetitor; dan Merger vertikal antara pemasok dengan konsumen atau pelanggannya, atau pabrikan dengan distributornya. Keempat, Merger segitiga (Triangle Merger), merupakan Merger antara dua perusahaan dinana asset, hak dan kewajiban dari salah satu perusahaan yang bubar tersebut, dialihkan kepada anak perusahaan dari perusahaan yang tetap exist tersebut. ${ }^{8}$

\section{Peleburan / konsolidasi}

8 Fred BG Tumbuan, 2007, Tugas dan Wewenang Perseroan Terbatas menurut UUPT PPh, Jakarta:Rajawali Press, hlm 22
Pengertian mengenai konsolidasi/peleburan tercantum dalam Pasal 1 angka (10) UUPT yang menentukan:

Peleburan adalah perbuatan hukum yang dilakukan oleh dua Perseroan atau lebih untuk meleburkan diri dengan cara mendirikan satu Perseroan baru yang karena hukum memperoleh aktiva dan pasiva dari Perseroan yang meleburkan diri dan status badan hukum Perseroan yang meleburkan diri berakhir karena hukum.

Dalam konsolidasi/peleburan, dua atau lebih Perseroan meleburkan diri sehingga yang kemudian muncul adalah satu Perseroan baru dengan status badan hukum dan nama yang baru, sedangkan nama dan status badan hukum Perseroan-Perseroan yang meleburkan diri menjadi hapus atau berakhir karena hukum. ${ }^{9}$

\section{Pengambilalihan / akuisisi}

Istilah yang banyak digunakan adalah "akuisisi", akan tetapi UU No. 40 Tahun 2007 tentang Perseroan terbatas dan peraturan Pemerintah Nomor 27 Tahun 1998 Tentang Penggabungan, Peleburan, dan pengambilalihan Perseroan Terbatas menggunakan istilah "pengambilalihan".

Istilah "Aktuisisi" tersebut berasal dari bahasa Inggris, "acquisition". Yang dimaksud dengan "acquisition" atau "take over" adalah pengambilalihan suatu kepentingan pengendalian perusahaan oleh suatu perusahaan oleh perusahaan lain (one company taking over controling interest in another company). Atau secara lebih gamblang, yang dimaksud dengan akuisisi (take over) adalah pengambilalihan perusahaan oleh perusahaan lain.

Pengertian dari "pengambilalihan" dapat ditemukan dalam pasal 1 angka (3) Peraturan Pemerintah Nomor 27 Tahun 1998 tentang penggabungan, peleburan, dan pengambilalihan Perseroan Terbatas yang menyatakan :

pengambilalihan adalah perbuatan hukum yang dilakukan oleh badan hukum atau orang Perseroan untuk mengambil alih baik seluruh ataupun sebagian besar saham Perseroan yang dapat mengakibat-

\footnotetext{
Munir Fuady, Op Cit, hlm. 7
} 
kan beralihnya pengendalian terhadap Perseroan tersebut.

Akuisisi dalam dunia hukum dan bisnis adalah setiap perbuatan hukum untuk mengambilalih sebagian atau seluruh saham dan atau aset suatu perusahaan. Namun demikian, baik undang-undang Nomor 40 tahun 2007 Tentang Penggabungan, Peleburan, dan Pengambilalihan Perseroan Terbatas mengartikan akuisisi perusahaan sebagai suatu akuisisi saham saja, tidak termasuk akuisisi aset atau akuisisi lain seperti akuisisi bisnis.

Pengaturan mengenai pengambilalihan PT diatur dalam berbagai peraturan perundangundangan. Meskipun telah dikeluarkan UUPT baru (Undang-Undang Nomor 40 Tahun 2007) sebagai pengganti UUPT lama (Undang-Undang Nomor 1 Tahun 1995), pengaturan mengenai pengambilalihan PT masih menggunakan peraturan yang lama yaitu Peraturan Pemerintah Nomor 27 Tahun 1998 tenang Penggabungan, Peleburan, dan Pengambilalihan Perseroan terbatas. Hal ini karena sampai dengan saat ini belum ada peraturan pelaksana yang baru mengenai pengambilalihan PT sebagaimana diamanatkan dalam Pasal 134 Undang-Undang Nomor 40 Tahun 2007 tentang Perseroan Terbatas, yang menyebutkan bahwa; Ketentuan lebih lanjut mengenai Penggabungan, Peleburan, atau Pengambilalihan Perseroan diatur dengan Peraturan Pemerintah.

Implementasi Penggabungan, Peleburan, dan Pengambilalihan Perseroan Terbatas

Dalam Undang-Undang nomor 40 Tahun 2007 tentang Perseroan Terbatas, di samping terdapat ketentuan yang mengatur akuisisi bersama-sama dengan Merger, konsolidasi dan pemisahan PT, terdapat pula ketentuan-ketentuan yang diperuntukkan khusus terhadap akuisisi PT. Ketentuan yang mengatur akuisisi bersama-sama dengan Merger, konsolidasi dan pemisahan PT diatur dalam Pasal 125 sampai dengan Pasal 128 dan Pasal 131 UUPT.

Dalam peraturan pelaksana UU No. 40 Tahun 2007 tentang Perseroan terbatas mengenai pengambilalihan PT, Peraturan Pemerin- tah Nomor 27 Tahun 1998 tentang penggabungan, Peleburan, dan Pengambilalihan Perseroan Terbatas, terdapat pula dua macam ketentuan, ketentuan yang mengatur akuisisi bersamasama dengan Merger dan konsolidasi PT dan ketentuan yang diperuntukkan khusus terhadap akuisisi PT. Ketentuan yang mengatur akuisisi bersama-sama dengan Merger dan konsolidasi PT adalah sebagai berikut :

Ketentuan yang mengatur pengambilalihan bersama-sama dengan penggabungan dan peleburan Perseroan diatur dalam Pasal 4, Pasal 5, Pasal 6, dan Pasal 33. Sedangkan ketentuan yang khusus mengatur mengenai pengambilalihan Perseroan diatur dalam Pasal 26, Pasal 27, Pasal 28, Pasal 29, dan Pasal 30 PP No 27 Tahun 1998.

Berikut akan dijabarkan dan dianalisis terlebih dahulu pasal-pasal yang mengatur pengambilalihan bersama-sama dengan penggabungan dan peleburan:

Pada dasarnya pengambilalihan Perseroan merupakan urusan "privat" dari masing-masing Perseroan yang melakukan pengambilalihan, namun demikian UUPT maupun PP No.27 Tahun 1998 tetap memberikan batasan-batasan dalam rangka pelaksanakan pengambilalihan Perseroan. Batasan-batasan ini sebagaimana diatur dalam Bab II PP No.27 Tahun 1998 mengenai syarat-syarat penggabungan, peleburan, dan pengambilalihan yang terdiri dari Pasal 4, 5, dan 6.

\section{Pasal 4 PP No 27 Tahun 1998 menyebutkan bahwa:}

(1) Penggabungan. Peleburan, dan Pengambilalihan hanya dapat dilakukan dengan memperhatikan :

a. Kepentingan Perseroan, pemegang saham minoritas dan karyawan Perseroan yang bersangkutan;

b. Kepentingan masyarakat dan persaingan sehat dalam melakukan usaha.

(2) Penggabungan, peleburan, dan pengambilalihan tidak mengurangi hak pemegang saham minoritas untuk menjual sahamnya dengan harga yang wajar. 
(3) Pemegang saham yang tidak setuju terhadap keputusan Rapat Umum Pemegang saham mengenai Penggabungan, peleburan, dan Pengambilalihan hanya dapat menggunakan haknya agar saham yang dimilikinya dibeli dengan harga yang wajar sesuai dengan ketentuan Pasal 55 UndangUndang Nomor 1 Tahun 1995 tentang Perseroan Terbatas.

(4) Pelaksanaan hak sebagaimana dimaksud dalam ayat (3) tidak menghentikan proses pelaksaan penggabungan, peleburan, dan pengambilalihan.

Dari ketentuan pasal tersebut di atas maka dapat diketahui bahwa dalam proses Penggabungan, Peleburan, dan Pengambilalihan harus memperhatikan kepentingan Perseroan, Pemegang saham minoritas, karyawan Perseroan maupun kepentingan masyarakat dan persaingan sehat dalam melakukan usaha. Hal tersebut harus senantiasa dikomunikasikan dengan para pihak yang terkait, sebelum, selama dan setelah proses Penggabungan, Peleburan, dan Pengambilalihan.

Selain perlindungan terhadap kepentingan Perseroan, pemegang saham minoritas dan karyawan Perseroan, PP No.27 Tahun 1998 juga mengatur mengenai perlindungan terhadap kepentingan dari para kreditor. Hal ini sebagaimana diatur dalam Pasal 5 PP No.27 Tahun 1998 yang menetukan bahwa: Penggabungan, Peleburan, dan Pengambilalihan juga harus memperhatikan kepentingan kreditor.

Dari ketentuan Pasal 4 dan Pasal 5 tersebut di atas, pada dasarnya untuk melindungi kepentingan para pihak yang terkait dan khususnya kepada kepentingan kreditor (Pasal 5). UUPT dan PP No.27 Tahun 1998 mensyaratkan kuorom Rapat Umum pemegang Saham yang lebih besar untuk pelaksanaan Penggabungan, Peleburan, dan Pengambilalihan dibandingkan dengan kuorom Rapat Umum Pemegang Saham Tahunan maupun yang diselenggarakan dalam rangka perubahan Anggaran Dasar Perseroan. Hal ini tidak lain dimaksudkan untuk melindungi kepentingan para pihak sebagaimana disebutkan dalam Pasal 4 dan Pasal 5 PP No. 27 Tahun 1998.
Pasal 6 PP No 27 Tahun 1998 menentukan bahwa:

(1) Penggabungan, peleburan, dan pengambilalihan hanya dapat dilakukan dengan persetujuan Rapat Umum Pemegang Saham.

(2) Penggabungan, peleburan, dan pengambilalihan dilakukan berdasarkan keputusan Rapat Umum pemegang saham yang dihadiri oleh pemegang saham yang mewakili paling sedikit $3 / 4$ (tiga perempat) bagian dari jumlah seluruh saham dengan hak suara yang sah dan disetujui oleh paling sedikit 3/4 (tiga perempat) bagian dari jumlah suara tersebut.

(3) Bagi Perseroan terbuka, dalam hal persyaratan sebagaimana dimaksud dalam ayat (2) tidak tercapai maka syarat kehadiran dan pengambilalihan keputusan ditetapkan sesuai dengan peraturan perundang-undangan di bidang Pasar Modal.

Dari ketentuan Pasal 6, dapat diketahui bahwa Penggabungan, peleburan, dan pengambilalihan hanya dapat dilakukan dengan Rapat Umum Pemegang Saham (RUPS), yang mana kuorum dalam RUPS adalah kuorum yang sangat besar yaitu $3 / 4$ yang hadir harus menyetujui. Apabila hal tersebut tidak tercapai maka Penggabungan, peleburan, dan pengambilalihan tidak lagi memakai ketentuan pasal 6, akan tetapi dengan ketentuan yang ada dalam Undang-undang Pasar Modal.

Ketentuan yang mengatur pengambilalihan bersama-sama dengan penggabungan dan peleburan Perseroan selain mengenai syaratsyarat yang harus dipenuhi, juga mengatur mengenai keberatan terhadap penggabungan, peleburan, atau pengambilalihan Perseroan. Hal ini sebagaimana diatur dalam Pasal 33 PP No.27 Tahun 1998 yang menentukan bahwa:

(1) Direksi wajib menyampaikan dengan surat tercatat Rancangan penggabungan, peleburan, dan pengambilalihan kepada seluruh kreditor paling lambat 30 (tiga puluh) hari sebelum pemanggilan Rapat Umum Pemegang Saham. 
(2) Kreditor dapat mengajukan keberatan kepada Perseroan paling lambat 7 (tujuh) hari sebelum pemanggilan Rapat Umum pemegang saham yang akan memutus mengenaii rencana penggabungan, pleburan, dan pengambilalihan yang telah dituangkan dalam rancangan tersebut.

(3) Apabila dalam jangka waktu sebagaimana dimaksud dalam ayat (2) kreditor tidak mengajukan keberatan, maka kreditor dianggap menyetujui penggabungan, peleburan, dan pengambilalihan.

(4) Keberatan editor sebagaimana dimaksud dalam ayat (2) disampaikan dalam rapat umum pemegang saham guna mendapat penyelesaian.

(5) Selama penyelesaian sebagaimana dimaksud dalam ayat (4) belum tercapai, maka penggabungan, peleburan, dan pengambilalihan tidak dapat dilaksanakan.

Dari ketentuan pasal tersebut di atas dapat diketahui bahwa Penggabungan, Peleburan, dan Pengambilalihan haruslah melalui pemberitahuan kepada kreditor dan apabila ada keberatan maka keberatan tersebut harus terselesaikan lebih dahulu. Pemberitahuan tersebut wajib bagi Direksi untuk disampaikan kepada kreditor sebelum RUPS dilaksanakan. Jika tidak ada keberatan dari pihak kreditor berarti kreditor menyetujui Penggabungan, Peleburan, dan Pengambilalihan. Ketentuan yang khusus mengatur tentang pengambilalihan/akuisisi PT adalah diatur dalam Pasal 26 sampai dengan 32 PP No 27 Tahun 1998.

\section{Pasal 26 PP No 27 Tahun 1998 menentukan} bahwa:

(1) Pihak yang akan mengambilalih menyampaikan maksud untuk melakukan pengambilalihan kepada direksi Perseroan yang akan diambilalih.

(2) Direksi Perseroan yang akan diambilalih dan pihak yang akan mengambilalih masingmasing menyusun Usulan Rencana Pengambilalihan.

(3) Usulan sebagaimana dimaksud dalam ayat (1) masing-masing mendapat persetujuan komisaris Perseroan yang akan diambilalih dan yang mengambilalih atau lembaga serupa dari pihak yang akan mengambilalih, dengan memuat sekurang-kurangnya :

a. Nama dan tempat kedudukan Perseroan sertta badan hukum lain, atau identitas orang perseorangan yang melakukan pengambilalihan;

b. Alasan serta penjelasan masing-masing Direksi Perseroan, pengurus badan hukum atau orang perseorangan yang melakukan pengambilalihan;

c. Laporan tahunan terutama perhitungan tahunan tahun buku terakhir dari Perseroan dan badan hukum lain yang melakukan pengambilalihan;

d. Tata cara konversi saham dari masingmasing Perseroan yang melakukan pengmbilalihan apabila pembayaran pengambilalihan dilakukan dengan saham;

e. Rancangan perubahan anggaran dasar Perseroan hasil pengambilalihan;

f. Jumlah saham yang akan diambilalih;

g. Kesiapan pendanaan;

h. Neraca gabungan proforma Perseroan setelah pengambilalihan yang disusun sesuai dengan standar akuntansi keuangan, serta perkiraan mengenai halhal yang berkaitan dengan keuntungan dan kerugian serta masa depan Perseroan tersebut berdasarkan hasil penilai ahli yang independen;

i. Cara penyelesaian hak-hak pemegang saham yang tidak setuju terhadap pengambilalihan perusahaan;

j. Perkiraan jangka waktu pelaksanaan pengambilalihan.

Pasal 27 PP No 27 Tahun 1998 menentukan bahwa:

Usulan sebagaimana dimaksud dalam pasal 26 merupakan bahan untuk penyusunan Rancangan pengambilalihan yang disusun bersama antara direksi Perseroan yang akan diambilalih dengan pihak yang akan mengambilalih.

Pasal 28 PP No 27 Tahun 1998 menentukan bahwa: 
Rancangan sebagaimana dimaksud dalam pasal 27 sekurang-kurangnya memuat hal-hal yang tercantum dalam usulan rencana pengambilalihan sebagaimana dimaksud dalam pasal 26.

\section{Pasal 29 PP No 27 Tahun 1998 menentukan} bahwa:

Ringkasan rancangan pengambilalihan sebagaimana dimaksud dalam Pasal 27 wajib diumumkan oleh direksi dalam 2(dua) surat kabar harian serta diberitahukan secara tertulis kepada karyawan Perseroan yang melakukan pengambilalihan paling lambat 14 (empat belas) hari sebelum pemanggilan Rapat Umum Pemegang Saham masing-masing Perseroan.

\section{Pasal 30 PP No 27 Tahun 1998 menentukan bahwa:}

Rancangan pengambilalihan wajib mendapat persetujuan rapat umum Pemegang Saham Perseroan yang akan diambilalih dan yang akan mengambilalih atau lembaga serupa dari pihak yang akan mengambilalih.

\section{Pasal 31 PP No 27 Tahun 1998 menentukan bahwa:}

(1) Rancangan pengambilaliahan yang telah disetujui sebagaimana dimaksud dalam Pasal 30 dituangkan dalam akta Pengambilalihan.

(2) Akta pengambilalihan sebagaimana dimaksud dalam ayat (1) dibuat dihadapan notaris dalam bahasa Indonesia.

\section{Pasal 32 PP No 27 Tahun 1998 menentukan} bahwa:

(1) Apabila pengambilalihan Perseroan terbatas dilakukan dengan disertai perubahan anggaran dasar sebagaimana dimaksud dalam pasal 15 ayat (2) Undang-Undang Nomor 1 Tahun 1995 Tentang Perseroan Terbatas, maka pengambilalihan mulai berlaku sejak tanggal persetujuan perubahan Anggaran Dasar oleh Menteri.

(2) Apabila pengambilalihan Perseroan dilakukan dengan disertai perubahan Anggaran Dasar yang tidak memerlukan persetujuan Menteri, maka pengambilalihan mulai berlaku sejak tanggal pendaftaran Akta Pengambilalihan dalam Daftar Perusahaan.

(3) Apabila pengambilalihan Perseroan tidak mengakibatkan perubahan Anggaran Dasar, maka pengambilalihan mulai berlaku sejak tanggal penandatanganan Akta Pengambilalihan.

Khusus mengenai Pengambilalihan sebagaimana diatur dalam Pasal 26-32 PP No.27 Tahun 1998, maka untuk Pengambilalihan prosedur yang harus ditempuh adalah dengan pembuatan suatu usulan rencana pengambilalihan ataupun Rancangan Pengambilalihan.

Dalam prakteknya proses demikian tidak digunakan karena selain tidak praktis juga para pihak yang berkepentingan, sebelumnya telah menyatakan dengan suatu Akta Notaris hasil dari keputusan di luar RUPS.

Selanjutnya keputusan di luar RUPS tersebut harus mendapat persetujuan dari seluruh pemegang saham baik dari pihak yang mengambilalih maupun pihak yang diambil alih. Persetujuan tersebut harus dituangkan dalam suatu Akta Pengambilalihan yang dibuat dihadapan Notaris dan dalam Bahasa Indonesia. Pengambilalihan tersebut baru mulai berlaku sejak tanggal persetujuan perubahan Anggaran Dasar yang diketahui oleh Menteri.

Berbeda dengan peleburan/konsolidasi, di dalam akuisisi tidak ada perusahaan yang meleburkan atau membubarkan diri, masingmasing perusahaan tetap ada atau eksis. Dalam perkembangannya ternyata akuisisi itu sendiri beraneka ragam yang dapat dipilah-pilah berdasarkan kriteria yang dipakai, kriteriakriteria tersebut adalah sebagai berikut:

Klasifiasi akuisisi dilihat dari jenis usaha

Apabila dilihat dari jenis usaha perusahaan-perusahaan yang terlibat dalam transaksi akuisisi, maka akuisisi dapat digolongkan berupa. Pertama, Akuisisi Horizontal. Dalam hal ini perusahaan yang diakuisisi adalah para pesaing yang memproduksi produk yang sama atau yang memiliki territorial pemasaran yang sama; Kedua, Akuisisi vertikal. Dimaksudkan sebagai akuisisi oleh suatu perusahaan terhadap perusahaan lain yang masih dalam satu mata rantai produksi, suatu perusahaan dalam arus 
pergerakan produksi dari hulu ke hilir; Ketiga, Akuisisi konglomerat. Akuisisi terhadap perusahaan-perusahaan yang tidak terkait baik secara horizontal maupun vertikal.

\section{Klasifikasi akuisisi dilihat dari lokalisasi}

Jika diihat dari segi lokalisasi perusahaan pengakuisisi dengan prusahaan target, Akuisisi dapat dikategorikan sebagai Pertama, Akuisisi Internal yaitu perusahaan-perusahaan yang melakukan akuisisi masih dalam satu grup usaha; Kedua, Akuisisi Eksternal merupakan akuisisi yang terjadi antara dua atau lebih perusahaan, masing-masing dalam grup yang berbeda.

\section{Klasifiasi akuisisi dilihat dari objek akuisisi}

Apabila dilihat dari objek akuisisi, maka bentuk akuisisinya berupa Pertama, Akuisisi Saham. Akuisisi dilakukan terhadap saham perusahaan target. Untuk dapat disebut sebagai transaksi akuisisi maka jumlah minimal saham yang diambilalih/dibeli adalah 51\%; Kedua, Akuisisi Asset. Akuisisi dilakukan terhadap asset-aset perusahaan target, dengan atau tanpa ikut mengambilalih seluruh kewajiban perusahaan target terhadap pihak ketiga. Sebagai kontraprestasi dari akuisisi asset, diberikanlah kepada pemegang saham perusahaan target suatu harga yang pantas. Ketiga, Akuisisi Kombinasi. Dalam hal ini akuisisi dilakukan terhadap kombinasi antara akuisisi saham dengan akuisisi asset. Demikian juga dengan kontraprestasinya, sebagian dibayar dengan tunai dan sebagian lagi dengan saham perusahaan pengakuisisi; Keempat, Akuisisi Bertahap. Akuisisi tidak dilakukan sekaligus. Misalkan perusahaan target menerbitkan convertible bonds, sementara perusahaan pengakuisisi menjadi pembelinya. Dalam hal ini, tahap pertama perusahaan pengakuisisi menaruh dana ke perusahaan target lewat pembelian bonds. Tahap selanjutnya bonds tersebut ditukar dengan equity. Dengan demikian hak opsi ada pada pemilik convertible bonds; Kelima, Akuisisi Kegiatan Usaha. Akuisisi hanya dilakukan terhadap kegiatan usaha dari peusahaan target termasuk jaringan bisnis, alat produksi, dan hak milik intelektual.

\section{Klasifiasi akuisisi dilihat dari motivasi akuisisi} Dilihat dari motivasi dilakukannya akuisisi, akuisisi dapat dibedakan menjadi: Pertama, Akuisisi Strategis. Akuisisi di latarbelakangi oleh keinginan untuk meningkatkan produktifitas perusahaan. Dengan akuisisi diharapkan dapat meningkatkan sinergi dan mengurangi resiko, memperluas pangsa pasar, meningkatkan efisiensi, dan sebagainya; Kedua, Akuisisi Finansial. Akuisisi dilakukan untuk mendapatkan keuntungan financial semata. Akuisisi ini bersifat spekulatif, dengan keuntungan yang diharapkan lewat pembelian saham atau asset yang murah, tetapi dengan income perusahaan yang tinggi.

\section{Klasifiasi akuisisi dilihat dari divestitur}

Pengklasifikasian akuisisi dapat pula dilihat dari devistur, dengan melihat peralihan asset/saham/manajemen dari perusahaan target kepada perusahaan pengakuisisi. Oleh karena itu akuisisi dapat diklasifikasikan berupa Pertama, Take over pencaplokan. Take over berarti "to assume control or management ofnot necessarily involving the transfer of absolute title; Kedua, Freezeouts dan squeezeouts. Freezeouts merupakan usaha-usaha dari pemegang saham mayoritas untuk memaksakan pemegang saham minoritas keluar dari perusahaan, sedangkan dalam squeezeouts, pemegang saham minoritas tidak dipaksa keluar secara langsung melainkan mereka dibuat sedemikian rupa sehingga akhirnya mereka keluar dari perusahaan dengan menjual saham yang dimiliknya; Ketiga, Management Buyouts yang merupakan terminologi yang ditujukan kepada sekelompok manajer dari suatu perusahaan tertentu yang membeli saham dari suatu perusahaan; Ketiga, Leveraged Buyouts. Yang dimaksud dengan istilah Leveraged Buyouts adalah suatu pembelian seluruh atau sebagian besar saham dari suatu perusahaan dengan dana yang dipinjam dari pihak ketiga.

Klasifiasi akuisisi dilihat dari model pembayaran 
Dilihat dari model pembayarannya, akuisisi dapat dibagi menjadi, Pertama, Akuisisi Dibayar Tunai; Kedua, Akuisisi Dibayar dengan Saham; Ketiga, Akuisisi Dibayar dengan Aset; Keempat, Akuisisi dengan system Pembayaran Kombinasi; Kelima, Akuisisi dengan Tahapan; Keenam, Akuisisi model Leveraged Buyouts (LBO)

\section{Akuisisi dengan inbreng saham}

Inbreng saham merupakan salah satu metode penytoran saham kepada perusahaan oleh pemebang saham, di mana saham tersebut disetor ddengan pemberian saham perusahaan lain. Dengan demikian setelah inbreng saham terjadi, perusahaan yang menerima penyetoran saham tersebut menjadi pemegang saham pada perusahaan lain.

\section{Akuisisi dengan cara share swap}

Share swap atau saling tukar saham adalah pertukaran saham antara satu perusahaan dengan perusahaan lainnya sehingga masingmasing perusahaan memegang saham satu sama lain.

\section{Penutup}

Berdasarkan pembahasan di atas maka dapat disimpulkan bahwa. Pertama, Dengan berlakunya UU No. 40 Tahun 2007 Tentang Perseroan Terbatas, maka PP No. 27 Tahun 1998 tentang Penggabungan, Peleburan, dan Pengambilalihan masih tetap berlaku. Hal ini sesuai dengan ketentuan Pasal 159 UUPT yang menyatakan bahwa Peraturan Pelaksanaan dari UU No.1 Tahun 1995 tentang Perseroan Terbatas dinyatakan tetap berlaku sepanjang tidak bertentangan atau belum diganti dengan yang baru berdasarkan UU ini; Kedua, Penggabungan, Peleburan, dan Pengambilalihan sebagaimana diatur dalam PP No. 27 Tahun 1998, penerapannya masih mendasarkan pada ketentuan Pasal 134 UUPT, yang menyebutkan bahwa ketentuan lebih lanjut mengenai Penggabungan, Peleburan, dan Pengambilalihan diatur lebih lanjut dengan Peraturan Pemerintah. 